\title{
DIE ROEPING TOT SIGBAARMAKING VAN DIE KATOLISITEIT VAN DIE KERK
}

\author{
Dr. P. J. Pelser
}

IN hierdie studie word die klem gelê op die sigbaarmaking van die katolisiteit van die kerk. 'n Algemeen-erkende term om die saak ,sigbaarmaking" aan te dui bestaan nie in Afrikaans nie." As sinonieme uitdrukkings word ook die woorde ,vergestalting, gestalte gewing, sigbare realisering en sigbare verwerkliking" gebruik.

Enersyds word die problematiek gevind in die belydenis dat die kerk met sy eienskappe 'n geloofsobjek is wat deur die geloof kenbaar is. ${ }^{2}$ Die katolisiteit is, soos die ander eienskappe, ook 'n eienskap van die onsigbare wese van die kerk. Die kerk het egter die roeping om sy onsigbare eienskappe in hierdie tyd en op hierdie aarde te realiseer. ${ }^{3}$ Die sigbaarmaking van die eienskappe van die kerk is God se werk, maar ook die roeping en verantwoordelikheid van die verlostes. Waar die feilbare en onvolkome mens God se werk tot openbaring moet laat kom, word altyd 'n spanning gevind. Kerke en groepe gee elk op sy eie wyse uitdrukking aan die roeping tot sigbaarmaking van die kerk. Vandaar ook die veelheid van antwoorde wat op hierdie problematiek gegee word.4

Andersyds is die sigbaarmaking van die katolisiteit problematies omdat elke kerk vanuit sy eie konfessie en kerkregeringstelsel daarop 'n antwoord gee.

Onderskei moet word tussen die sigbaarwording van die kerk en die sigbaarmaking daarvan. By die sigbaarwording tree die kerk as organisme op die voorgrond, soos dit in die wandel van die gelowiges openbaar word. By die sigbaarmaking word die aandag hoofsaaklik op die organisasie van die kerk gevestig. ${ }^{5}$

\section{1) Historiese ontwikkeling van die begrip katoliek}

Die begrip katoliek (katolisiteit) word in die Skrif slegs in Hand. 4 : 18 gevind en, soos by die oudste Christelike skrywers ook, is dit in ' $n$ nie-teologiese sin gebruik. As tegniese term vir die katolieke eienskap van die kerk kom dit nie in die Skrif voor nie. Vanaf die $2 \mathrm{e}$ eeu n.C. is dit gebruik om een van die eienskappe van die kerk aan te dui.

Sover bekend het Ignatius, biskop van Antiochië, dit die eerste gebruik $^{0}$ en reeds in hierdie eerste gebruik kan duidelik twee lyne in die begrip katolisiteit onderskei word: die kwalitatiewe en kwantitatiewe. Na gelang die katolisiteit vanuit die kwalitatiewe of kwan. titatiewe, dic vertikale wortel of horisontale voortgang benader word, kan spanning en botsing deur die eeue in die katolisiteitsbeskouing aangetoon word. Vir Ignatius was die kerk katoliek in soverre dit die volheid en volkomenheid van Jesus Christus vertoon en meedeel. Hy het van die gegewe volheid uitgegaan om dit sigbaar in die kerk te vergestalt. Die harmonie tussen die twee lyne 
is dat vanuit die kwalitatiewe, onsigbare volheid die kwantitatiefsigbare sy van die kerk tot volheid moet groei.

Geleidelik het die klem al sterker op die sigbare, waarneembare in die katolisiteit geval. Reeds by Irenaeus het katoliek die norm teenoor ketters geword met die betekenis van regsinnigheid wat die kerk as egte Christuskerk stempel. ${ }^{7}$ Gedurende die $3 \mathrm{e}$ eeu het die sigbare element in die katolisiteitsbegrip oorheersend geword toe katoliek die onderskeidingsteken van die ware kerk teenoor dwaalrigtings geword het - die apologetiese gebruik van die term. ${ }^{8}$ In die $4 \mathrm{e}$ eeu was katoliek sinoniem met regsinnigheid gebruik. Vir Augustinus het die katolisiteit van die kerk meer in die objektiewe instituut met sy leer, genademiddels en kultus as in die lede van die kerk gelê. Hy wou dit wel nog uit die heilsvolheid verklaar, maar die ware katolisiteit word geken soos dit vergestalt is in die organisasie van die kerk. ${ }^{\circ}$ So is in die $4 \mathrm{e}$ eeu die oorspronklike orde in die begrip omgekeer, naamlik dat nie meer vanuit die vertikale na die horisontale dimensie beweeg is nie.

By die verdere ontwikkeling van dié begrip in die Westerse kerk is die sigbare sy van die kerk as uitgangspunt geneem. Die kerk besit volgens sy sigbare gestalte die volheid en behou ook die pleroma. ${ }^{10}$ In die Oosterse kerk is die katolisiteit as 'n gawe beskou wat sigbaar en kenbaar aan die kerk behoort en waarvan uitgegaan moet word om na die innerlike grond te beweeg. ${ }^{11}$

Gedurende die Middel- en die laat Middeleeue is die sigbare lyn na die uiterste konsekwensie deurgetrek. Katoliek kan alleen wees wat in gemeenskap met die sigbare instituut van die kerk, die hiërargie, verkeer soos dit onder die sigbare hoof, die pous, saamgevat is. Die kerk as objektiewe heilsinstituut is die enige ware kerk.

$\mathrm{Na}$ die Reformasie het die Rooms-Katolieke teologie op die kwantitatief-horisontale spoort voortbeweeg. Eers in die $20 \mathrm{e}$ eeu het ' $n$ swaai by sommige Roomse teoloë na die kwalitatiewe opvatting gekom. ${ }^{12}$ Die Tweede Vatikaanse Concilie (1962) het geensins van die ou opvattings aangaande die kerk afgewyk nie, maar slegs die histories-dinamiese aspek beklemtoon. Die moontlikheid om die katolisiteit sigbaar te vergestalt, is ingeperk deur die RoomsKatolieke Kerk se hiërargiese kerkstruktuur, die Primaat van Petrus en die leer van die kerk as algemene heilsmiddelaar.

Die Angel-Saksiese diskussies t.o.v. die katolisiteit gaan om die sigbare manifestasie daarvan. Enersyds word dit langs die weg van sintese en andersyds langs die weg van die geloof gesoek. Hoewel die Evangeliese groep binne die Anglikaanse Kerk die kwalitatiewe lyn wil beklemtoon, word die katolisiteit tog hoofsaaklik in die een omvattende struktuur van die kerk gevind. ${ }^{13}$

Vir Luther en die Lutherse teoloë met hulle soteriologiese uitgangspunt is die katolisiteit dit wat oral en deur almal ooreenkomstig die Skrif geglo word sonder om dit sigbaar in die struktuur van die kerk te manifesteer. Uit reaksie teen die Rooms-Katolieke Kerk se kwantitatief-horisontale opvatting het Luther die katolisiteit in die kwalitatief-vertikale geplaas. Luther kon die dualisme natuur-genade nie oorwin nie. Selfs by die teoloë wat die „evangeliese" katolisiteit voorstaan, bly die sigbaar-kwantitatiewe van sekondêre belang. ${ }^{14}$ 
Schleiermacher met sy subjektiewe uitgangspunt laat die sigbare, institutêre vorm van die kerk in diens van die onsigbare staan. Die uiterlike, sigbare gestalte van die kerk moet op die werk van die Heilige Gees betrek wees. ${ }^{16}$ Eintlik het hy die kwantitatiewe heeltemal aan die kwalitatiewe opgeoffer. Ook die Dialektiese teologie het die band tussen die kwalitatiewe en kwantitatiewe aspekte van die katolisiteit nie tot sy reg laat kom nie. Die begrip katoliek is met "Selbigkeit", die kontinuiteit in alle verskeidenheid, gevul. Die begrip katolisiteit is van die kwalitatiewe opvatting losgemaak en met 'n ander inhoud gevul. ${ }^{10}$

Dit was Calvyn wat die verhouding tussen die kwalitatiewe en kwantitatiewe aspekte in die katolisiteit versoen het. Hy het dit nie as parallel langs mekaar of as 'n teenstelling gesien nie, maar dat die een uit die ander groei. Die kerk met sy eienskappe is 'n indikatief en uit hierdie gegewe pleroma, wat die onsigbare wese van die kerk is, kom die sigbare gestalte van die kerk wat as imperatief horisontaal verwerklik moet word. ${ }^{17}$

Die uitgangspunt van die Gereformeerde teoloë en die Gereformeerde belydenisskrifte is dat die kwantitatief-horisontale uit die kwalitatief-vertikale groei. Enersyds word so die soewereiniteit van God en die heerskappy van Christus gehandhaaf. Die katolisiteit van die kerk is 'n gawe van God. Ook word andersyds die roeping en verantwoordelikheid van die uitverkore volk van die Here bely deur die katolisiteit as opdrag om tot die volheid te kom.

Hierdie imperatief en eis om tot volheid te kom, beteken nie slegs om tot 'n geestelike, kwalitatiewe pleroma te kom nie, maar ook tot 'n sigbare, kwantitatiewe volheid. Ook in die struktuur van die kerk moet die katolisiteit konkrete gestalte aanneem. Op hierdie punt verskil Kuyper radikaal van die ander Gereformeerde teoloë. Hy verwerp die gedagte dat die attributa in die struktuur van die kerk sigbare gestalte gegee moet word. ${ }^{18}$

\section{2) Fundering van die katolisiteit van die kerk}

2.1. Onmiskenbaar word die katolisiteit deur die Heilige Skrif in die werk van skepping en herskepping van die Drie-enige God gevind. ${ }^{10}$ Die skepping is die groot Goddelike daad van sigbaarmaking waarop die sigbaarheid van die kerk rus. Die eenheid van die skepping en die skepping van die mens uit een bloed is die basis waarop die kerk as katolieke kerk gebou is. ${ }^{20}$ In die heilsgeskiedenis word die deurbreking van Israel se afsondering konkreet gestel, telkens as ' $n$ inlywing in die sigbare Israel. ${ }^{21}$ Die teokratiese koningskap in Israel moes 'n voorafskaduwing van die omvattende en ewige Koningskap van die Messias, die Hoof van die kerk, wees. Dikwels is Ps. 87 die locus classicus vir die katolisiteit van die kerk genoem. Van hierdie Psalm skryf Grosheide: „Zo is dit Sions heerlijkheid, dat niet slechts de Jood, maar elk van de volken daar geboren en dat dit Sion, zo bewoond, door den Allerhoogste zelf wordt bevestigd. God handhaaft Jeruzalem, maar zo als het geworden is naar Zijn heilig bestel, een stad, bewoond door allen, die hun zaligheid vonden bij den Christus Gods". ${ }^{22}$ 
Van die profetiese werke in die Ou Testament verklaar $\mathrm{H}$. du Plessis: „Só universeel is die profetiese visie en só allesomvattend en soseer gaan dit om die heil van die mensheid, van die ware volk van God uit al die volke, dat die nie-gereddes feitlik nie eers in rekening gebring word as daar oor die heil vir die volke gespreek word nie. Hulle is maar net die droë takke wat van die mensheidsboom afgeval het. Hulle is die skuim wat in die smeltkroes afgeskei word, die kaf wat van die dorsvloer weggewaai word". ${ }^{23}$

In die Nuwe Testament, veral in die briewe van Paulus, word die katolisiteit van die kerk in Christus en sy omvattende en genoegsame verlossingswerk gefundeer.

2.2. Die universele heilsgenade verleen aan die kerk sy katolieke karakter. Die katolisiteit van die kerk moet vanuit hierdie grondprinsipe verklaar word: die universele heil in Christus met sy sola gratia-karakter. Die toepassing van die heil deur die Heilige Gees loop uit op die vorming van die Godsvolk; dus 'n sigbare realisering van die genadewerk van Christus. Hieruit blyk duidelik die sigbare lyn van die universele, die katolieke. Die universele heil en genade word en moet sigbaar verwerklik word.

2.3. Dogmaties-konfessioneel moet die katolisiteit uit die Trinitariese begronding van die kerk verklaar word. Die kerk is uit God. Die realisering van die kerk uit God in die tyd wys veral op twee grondpilare: die predestinasie en die verbond. Die diepste grond is die verkiesing van Christus met sy kosmiese betekenis om alles onder een hoof saam te voeg ${ }^{24}$ en dan die verkiesing in Christus. ${ }^{25}$ Die katolieke karakter van die kerk word duidelik deur die verkiesing in Christus openbaar omdat dit om die geheel gaan. Deur die verbond word die katolieke karakter van die kerk gerealiseer en tot sigbare openbaring gebring.

Die kerk is ook deur God. As vergadering van die gelowiges wat in Christus uitverkies is, het dit 'n Christologiese karakter. ${ }^{26}$ Die katolisiteit van die kerk moet ook in hierdie Christologiese bestaanswyse van die kerk begrond word. Van belang is veral Christus as die Hoof van sy kerk en as Koning daarvan. Deurdat die kerk 'n organisme, 'n liggaam is en Christus die Hoof word dit primêr aan die hele menslike geslag gebind. Die kerk is 'n volledige en groeiende organisme; dit dra die pleroma van Christus, maar moet ook tot volheid groei. Soos die Koningskap van Christus die sui generiskarakter van die kerk vorm, ${ }^{27}$ so is die goue draad wat deur die katolisiteit loop die genadeheerskappy van Christus, waardeur die katolisiteit verwerklik word. Die Koningskap van Christus stel die kerk in universele band met die „universele" Christus, die Christus Pantokrator, waarin die belydenis van skepping, verlossing en voleinding verbind is. ${ }^{28}$ Deur die leer van die munus triplex word Christus se Koningskap as ten volle Messiaans gekarakteriseer. Die uiteindelik doel van die genadeheerskappy is om die pleroma van Christus deur die volle, volledige, gerealiseerde genade heerskappy in sy gemeente en die hele skepping te bring, om die katolisiteit sigbaar te vergestalt.

Die kerk tot God bring by sy pneumatiese fundering wat mede die katolieke karakter bepaal. Christus konstitueer en vervul in 
die krag van en deur die Heilige Gees sy liggaam. Deur die werk van die Heilige Gees is die kerk 'n werklikheid en neem dit op aarde gestalte aan. ${ }^{29}$ Die Heilige Gees lyf elke gelowige as 'n volle persoon, liggaam en siel, in in die liggaam van Christus. So maak die Heilige Gees die kerk sigbaar op aarde. Die beelde van liggaam, tempel en gebou bevestig dat die kerk katoliek is en dat dit 'n konkrete, sigbare gestalte het. Die institutêre vorm van die kerk met sy instrumentele ingesteldheid is die wyse waarop en die plek waar die katolisiteit sigbaar gemaak word.

Wie na die werk van die Heilige Gees in die kerk kyk, merk die eskatologiese aspek, waardeur die kerk in die raamwerk van die voorlopigheid en die toekomstigheid van die koninkryk van God geplaas word. Die kerk as ecclesia militans moet voortgaan na die ecclesia triumphans, daarom het die katolisiteit 'n dinamiese karakter. Die katolisiteit van die kerk is die eienskap wat die kerk se aanstuwing op die koninkryk openbaar: dit gryp eskatologies na die volheid van alles en almal in God.

\section{3) Die sin en inhoud van die katolisiteit}

Om die rykdom en diepte van die katolisiteit van die kerk te verstaan is die onderskeiding: kwalitatief-kwantitatief, noodsaaklik. Die enige, heilige, katolieke kerk sien in eintlike sin op die vergadering wat God deur sy verborge verkiesing aangeneem het en wat deur die geloof gegryp is. ${ }^{30}$,In eigenlijke zin gaat het over de kerk naar haar geestelijke, onzienlijke zijde..." ${ }_{31}$ Die kerk is die vrug van die herskepping, wat die blye boodskap van vernuwing aan alle kreature is, ${ }^{32}$ daarom is die Christendom vir Bavinck 'n godsdienstig-sedelike krag wat immanent in die natuurlike ingaan en alle onreinheid verban. ${ }^{33}$ Vanuit hierdie kwalitatiewe aspek van die katolisiteit groei dan die kwantitatiewe, wat daaruit bestaan dat die kerk sonder uitsondering alle gelowiges uit alle volke, deur alle tye, op alle plekke, in alle kerke omvat. Die kerk vind sy katolieke karakter alleen in die duursame verbondenheid wat Christus tot stand bring; soos die wynstok en die lote verbonde is.

Die sin van die katolisiteit word in die Heilige Skrif in die begrippe „volheid" (pleroma) en ,vervul” (pleroen) gevind. Daardeur word die paradys- en herskeppingsmotief teenoor die gebrokenheid as gevolg van die sondeval geopen. Veral in die briewe van Paulus aan die Efesiërs en Kolossense het die begrippe pleroma en pleroen ' $n$ besonder gelaaide betekenis. ${ }^{34}$ Die gedagtegang in hierdie pleroma-tekste is kortliks soos volg: In absolute sin is God self dié Pleroma. ${ }^{35}$ Hierdie eie Goddelike volheid moet in die sin van die alomvattendheid van God se mag oor die wêreld gesien word. God vervul alles aktief. Die volheid van God woon liggaamlik in Christus. ${ }^{30}$ Christus, die Hoof, se posisie ten opsigte van die hele geskape werklikheid word in terme van sy heerskappy uitgedruk. Vervulling van alles beteken dat Christus met sy alomteenwoordige krag alles heersend deurdring, m.a.w. 'n heersende en in besit nemende vervulling. In besonder is die kerk Christus se pleroma. Die kerk is in aktiewe sin sy pleroma as die gebied of domein wat 
deur Hom vervul word, die oord waar Christus sy volheid neerlaat. ${ }^{37}$ Die Hoof vervul die liggaam en die liggaam word weer die volheid van die Hoof genoem. Die kerk se volheid is in Christus, die Hoof. Dit is ' $n$ bestaande realiteit in Christus en word as 'n gawe aan die kerk gegee. Pleroma beteken veral Christus se volle heerskappy, sy volle seggenskap. Deur die onmisbare werk van die Heilige Gees reik die liggaam na die volheid. So werk die Heilige Gees organies in die kerk. God skakel die mens deur sy Gees aktief en verantwoordelik in om tot volheid te kom. Dit is 'n opdrag. ${ }^{38}$ Die kerk moet in sy totaliteit volgroeid word, ' $n$ volwasse man, tot die mate van die volheid in Christus. Dit is om meer en meer in die genadeheerskappy van Christus te groei. ${ }^{39}$

Die volheid is ' $n$ gawe van God in Christus en deur Christus. Daarby is dit ook 'n proses waarin die kerk en die indiwiduele gelowige van Christusweë betrokke is. Die paradoks tussen indikatief en imperatief kom ook weer hier tot uitdrukking: die kerk is die volheid in Christus maar moet ook steeds vervul word en as 't ware na die volheid toe groei. Een van die grondelemente van Paulus se prediking is egter die eenheid van indikatief en imperatief. Die gelowige moet word wat hy in Christus is. ${ }^{40}$ Die kerk is voortdurend vanuit die indikatief via die imperatief op weg na die futurum, ,van haar rechtvaardiging via haar voortgaande heiliging naar haar verheerlijking". ${ }^{11}$

Die inhoud van die katolisiteit van die kerk is die genade en genadeheerskappy van Christus. Deur die genadeheerskappy, en die imperatief tot onderwerping daaraan, word die kerk gelei en begelei op sy weg na die volle realisering van die katolisiteit, na die pleroma, na die eskatologiese voleinding. Die katolisiteit word sigbaar gerealiseer in die gehoorsaamheid, diens en lewe in die kerk as openbaringspunt van die koninkryk van God.

\section{4) Die doelstelling vir die kerk in die katolisiteit}

Vanuit die katolisiteit word universele, wêreldwye, tydsomspannende en volheidsperspektiewe as roeping vir die kerk gestel waarheen dit moet werk. Dit is die ecclesia militans, die sigbare kant van die kerk, wat tot roeping het om die pleroma te bereik. Om hierdie doel te bereik strek die kerk se roeping in tweërlei rigting: 'n soteriologiese na binne en 'n kosmologiese na buite. Die kerk het as roeping om die gelowiges deur die bediening van die Woord en sakramente en deur die beoefening van die gemeenskap van die heiliges tot die pleroma van Christus die Hoof te vergader en te bring. Hierdie pleroma van Christus strek hom oor alle lewensterreine uit en omvat die mens in sy totale menswees. ${ }^{42}$

Hierdie groei na die volheid en die volheid self is en mag alleen 'n volheid in Christus wees. ${ }^{43}$ Die groei na die volheid is geen vanselfsheid nie, maar word gestruktureer deurdat die kerk hom aan Christus hou ${ }^{44}$ in Wie die heil in volstrekte sin gevind word.45 Die katolisiteit van die kerk as uitgangs- en eindpunt, gawe en opdrag, beteken dus: Christus alleen. So word duidelik dat katolisiteit primêr 'n eksklusiewe begrip is: in Christus alleen. 
Die katolisiteit vereis 'n bepaalde struktuur wat die dominium Christi as uitgangspunt afbaken en die groei na die eindpunt begelei en bevorder. ${ }^{46}$ Die kerk is nie alleen coetus, maar ook mater fidelium; organisme en ook instituut; doel en middel tegelyk.47 Dit is die wil van Christus dat die kerk op aarde geinstitueer bestaan. Self het $\mathrm{Hy}$ vir die kerk 'n passende institutêre vorm gegee.48 So het die institusionele vorm van die kerk alleen sin en betekenis as dit ten volle en direk op die pleroma van die kerk as liggaam van Christus betrek bly.

Die struktuurelemente is wat hulle bestaan, karakter en doel betref, ingestel op die vertikale dimensie van die kerk, die dominium Christi. Terselfdertyd moet dit ook op die horisontale dimensie gerig wees. Die ware katolisiteit is dan die uitdra van die vertikale in en deur die horisontale, van die geheim van die kruis tot aan die uiterste van die aarde. Dieselfde struktuur vir die vertikale en horisontale dimensies word vereis. Dit is immers twee dimensies van dieselfde saak, soos daar ook maar net een pleroma is met twee dimensies: 'n kwalitatiewe en kwantitatiewe.

Die ecclesia militans het die roeping om deur die struktuurelemente die kerk na sy ware wese tot volheid te bring en so ook die katolisiteit sigbaar te vergestalt. Die struktuur moet ook in die horisontale tot by die uiterste van die aarde gerealiseer word.49 Tot hierdie struktuurelemente behoort onder andere die instituering van die plaaslike kerk en besonder die instituering van die kerkverband, wat 'n middel is waardeur die katolieke karakter van die kerk sigbaar vergestalt word.

\section{5) Die geopenbaarde waarheid as norm by die sigbaarmaking van die katolisiteit}

God het die sin, inhoud en doel van die katolisiteit bepaal, maar ook die weg waarlangs en die wyse waarop dit sigbaar gemaak moet word. Soos die geopenbaarde waarheid van God die norm is wat tussen ware en valse kerk skeiding maak, is dit ook die norm waaraan die ware katolisiteit geken word. Die katolisiteit as opdrag moet volgens die Skrifwaarheid sigbaar gemaak word. Die ware kerk is altyd katolieke kerk en dus is die merktekens van die ware kerk ${ }^{50}$ ook merktekens waaraan die katolisiteit gemeet moet word. Hierdie merktekens geld ook as toetsstene vir die ware katolisiteit. Die ware katolisiteit is die volheid binne die geopenbaarde waarheid van God. Katolisiteit mag alleen 'n katolisiteit in die waarheid wees.

\section{6) Faktore wat die sigbaarmaking van die katolisiteit strem of bevorder}

Die prinsipiële riglyne moet na die praktyk deurgetrek word en toetsend op teologië, konfessies en kerkregeringstelsels toegepas word. Ook die huidige ekumeniese bewegings moet getoets word om te bepaal of hulle die ware sigbaarmaking van die katolisiteit van die kerk is.

6.1. Daar is eksterne en interne weerstande teen die groei van 
die kerk tot sy volheid. Die veld van eksterne weerstande en aanvalle op die kerk is byna onoorsienbaar. Tog het die kerk die roeping om die ryk van die duisternis te oorwin, om sy grense uit te brei deur verowering op die wêreld en die Satansryk, om tot die eindes van die aarde alles en almal onder die heerskappy van Christus te bring. ${ }^{51}$ Van veel groter belang vir die roeping om die katolisiteit sigbaar te maak, is om die interne weerstande in die kerk self te identifiseer en te oorkom.

Dit spreek vanself dat die katolisiteit as die relasie van Christus tot die geheel en van die geheel tot Christus in die verhouding van Christus tot die lidmate en van die lidmate tot Christus lê. Namate die getal van die uitverkorenes vol word in die kerk en elke indiwiduele lidmaat opgroei tot die volle grootte van geestelike volwassenheid in Christus, groei die kerk in katolisiteit. Die groei van die liggaam en die volheid van die liggaam lê enersyds in die groei en volheid van die lede. Andersyds is die volheid van die liggaam ook weer meer as net die getal van die afsonderlike lede en hulle indiwiduele volheid. Die volheid van die liggaam van Christus lê in die harmoniese saamvoeging van die lede tot een liggaam onder een Hoof. In die ecclesia militans beteken hierdie harmoniese saamvoeging onder een Hoof die sigbare realisering van die katolieke kerk. Dit is juis die verhouding van die geheel tot Christus, die liggaam as liggaam, die volheid van die geheel, wat die katolieke eienskap van die kerk is. In Efesiërs en Kolossense word veelvuldig die begrip „ta panta” (alles, almal, alle dinge) aan die pleromagedagte-verbind.

6.2. Van beslissende belang vir die katolisiteit van die kerk is om as uitgangspunt die leer van die uitverkiesing te neem, want daardeur word die katolisiteit as gawe, as kwalitatiewe volheid van God se genade aan sy verloste volk volgens sy soewereine wil ten volle gehandhaaf. Volgens Berkhof beperk die uitverkiesingsleer die katolisiteit van die kerk en strem die groei na die volheid omdat dit die versoenende sterwe van Christus tot die uitverkorenes beperk. $^{53}$ Die Dordtse Leerreëls bely daarteenoor dat Christus se „,kosbare dood... hom sou uitstrek tot al die uitverkorenes om hulle alleen met die regverdigmakende geloof te begiftig..." ${ }^{54} \mathrm{Die}$ katolisiteit word sigbaar gemaak as die uitverkore volk van God uit die mensheid tot volheid as die nuwe mensheid onder die genadeheerskappy van Christus gelei word.

6.3. Die dominium Christi onder die geheel word verhinder en beperk waar teologies van die standpunt uitgegaan word dat Christus slegs vir 'n deel van die menselewe van beslissende betekenis is. ${ }^{55}$ So byvoorbeeld deur Luther se leer van die twee ryke ${ }^{50}$ wat hy deurtrek tot 'n skeiding van liggaam en siel, die stoflike en die geestelike. ${ }^{57}$ Die dualisme van natuur en genade is nie heeltemal deur Luther oorwin nie. Die uiterlike lewe van die Christene word tot die wêreldryk gereken, want die Evangelie verander alleen die inwendige, die gemoed, die hart. ${ }^{58}$ Die spiritualistiese uitgangspunt van die Piëtisme en Metodisme verplig om die volheid tot 'n deel van die mens se lewe, naamlik die gevoel, die subjektiewe sielelewe te beperk. Ook die Rasionalisme kan nie tot die ware katolisiteit kom 
nie, omdat dit as uitgangspunt 'n enkele funksie van die mens, die menslike rede, geneem het. Juis die menslike rede wat as outonome grootheid verselfstandig is, het die godsdiens in deīstiese bane gelei. ${ }^{59}$ Agter die supranaturalisme lê die deîsme verskuil, wat leer en lewe van mekaar skeur, ${ }^{\circ 0}$ en so die betrokkenheid van Christus met sy genade en heil op die geheel verlore laat gaan. Deur pogings om die Christendom in verskillende geestesvermoëns van die mens te veranker, in die rede, gevoel of wil, het die absolute karakter van die Christelike godsdiens in gedrang gekom. ${ }^{81}$ Die absolute karakter van die Christelike godsdiens is juis 'n onmisbare voorwaarde om die katolisiteit van die kerk tot sigbare uitdrukking te bring, omdat dit waarborg dat die katolisiteit ten volle 'n gawe is, maar ook 'n opdrag wat onder die soewereine heerskappy van Christus volbring moet word.

Berkhof beskou die dialektiese teologie van Barth met sy streng , christocentrische exclusiviteit en haar universele inclusiviteit... als de meest katholieke na Calvijn". ${ }^{22}$ Vanuit sy negatiwiteitsbeskouing veroordeel Barth 'n organiese groei of bou van die koninkryk van God, omdat daardeur ,die kritische verhouding tussen menschelijke negativiteit en Goddelijke positiviteit gestoord zijn". ${ }^{33}$ Die katolisiteit van die kerk is vir Barth nie 'n groei tot die pleroma nie, maar dit word eskatologies na die hiernamaals verplaas.

6.4. Zuidema oordeel dat die meeste huidige ekumeniese bewegings se beskouing is dat konfessionele binding ' $n$ struikelblok op die pad tot die realisering van die katolisiteit is want elke konfessie moet as 'n tydverskynsel en nie-katoliek beskou word. ${ }^{64}$ Hierteenoor moet gehandhaaf word dat die aksent in die belydenis nie op die dinamiese nie maar op die statiese, die vastheid en duur val.05 Die kerk is pilaar en grondslag van die waarheid. Nadruk val op die kontinuïteit. Konfessionele binding as sodanig is nie 'n verhindering vir die ware katolisiteit nie. Deur sy konfessie word die rykdom en volheid van die genade tot uitdrukking gebring om daarin na die volkomenheid te groei. Die konfessie van die kerk is ' $n$ onmisbare hulpmiddel om tot geestelike volheid te groei.

Calvyn se betekenis vir die katolisiteit van die kerk lê in sy strewe om die heerskappy van Christus in die kerk en wêreld te realiseer. Hy wou die hele lewe, innerlik en uiterlik, heilig en onder die heerskappy van Christus bring. ${ }^{68}$ Die realisering van die peroma in die kerk, en dus ook Christus se heerskappy, beide na die innerlike en uiterlike, vereis dat die soewereine gesag van sy Woord bely word. Die sola scriptura van die Reformasie, wat in die konfessies van die Gereformeerde kerke beliggaam is, open die weg tot die ware katolisiteit. Die tweede pilaar waarop die katolisiteit as pleroma van die kerk rus is die sola gratia. Daardeur word die pleroma as gawe gehandhaaf. Enersyds kom dit tot openbaring in die belydenis van die totale verdorwenheid van die mens en sy onbekwaamheid om enige goed te kan doen. ${ }^{67}$ Andersyds blyk dit uit die belydenis van die absolute genoegsaamheid van die genade in Jesus Christus. ${ }^{\text {es }}$

Ook by die deelagtig word van die volheid, die realisering van die genade in die mens, moet die absolute en genoegsame karakter 
van die sola gratia gehandhaaf word. Dit het die Gereformeerde konfessies in die sola fide uitgewerk. Die volheid as gawe word sola fide toegeëien. Hierdie kwalitatiewe volheid moet verder sigbaar word en dit word gestel in die soli deo gloria, die betrekking van alles en almal in hierdie skepping op die eer van God. Die deelagtig word van die pleroma bring nie slegs 'n passiewe volheid nie, maar ook die roeping om aktief tot volheid te kom. ${ }^{\circ 9}$

Op die voetspoor van Calvyn open die Greeformeerde konfessies die weg om die absolute en soewereine genade en heerskappy van Christus in die ecclesia militans te vergestalt.

6.5. Naas die teologiese en konfessionele belemmerings kan nog op ' $n$ derde gebied hindernisse teen die sigbare realisering van die katolisiteit bestaan, naamlik op die terrein van die kerkregering. In die kerkregering moet die regering van Christus as Hoof oor sy kerk sigbaar realiseer word. In die kerkregeringstelsel moet die kwalitatiewe volheid, die pleroma as gawe, beliggaam wees in die absolute en soewereine mag en gesag van Christus, die Hoof van die kerk, en in sy Woord, die volle Heilige Skrif. Gemeet hieraan kan die Rooms-Katolieke kerkregeringstelsel nie tot die ware katolisiteit lei nie omdat die pous nie slegs die ,plaasvervanger van Christus, die Hoof, geword het nie, maar die verplaser". ${ }^{70}$ Die Lutherse of territoriale kerkregeringstelsel laat die regering van Christus oor sy kerk heeltemal in die Woordbediening opgaan. Die kerkregering het in die dualisme siel-liggaam, geestelik-natuurlik bly vassteek. Die Christelike owerheid moes die vakuum in die organisasie van die kerk vul. ${ }^{11}$ Die sigbaar-institutêre deel van die katolisiteit het by die Lutherse kerk agterweë gebly. In die Episkopaalse stelsel, soos dit by die Anglikaanse Kerk gevind word, word bely dat Christus nie eerstens deur sy kerk sy volk regeer nie maar deur die wêreldse vors. Die tweespalt tussen kerkregering en leer, vorm en inhoud, uiterlike organisasie en innerlike geloof beperk die katolisiteit tot 'n sintese van rigtings en belydenisse, sonder 'n eenheidsbelydenis van die geopenbaarde Waarheid. ${ }^{72}$ Hoewel die Kollegialistiese stelsel ook as vertrekpunt Christus as Hoof van die kerk wil neem, ${ }^{73}$ is die regering van Christus verdring deur die gesag van die volksoewereiniteit. Die regeermag berus by die kerklede. Die gemeentelede dra hulle gesag aan die ampsdraers as hulle organe en verteenwoordigers oor. ${ }^{74}$ Die kerkverband kom in die Kongregasionalistiese en Independentistiese stelsel van kerkregering nie tot sy reg nie. Die plaaslike outonome kongregasie word so beklemtoon dat die kerk nooit in breër verband as liggaam kan funksioneer nie. ${ }^{75}$ Deur die miskenning van 'n kerkverband word die weg na die sigbaarmaking van die katolisiteit grootliks gesluit.

Die uitgangspunt en bepalende in die Gereformeerde of Presbiteriale kerkregeringstelsel is die Skriftuurlike grondbeginsel dat Christus self sy kerk regeer. ${ }^{70}$ Die regering van die kerk word deur God se Woord bepaal. Die kerk is nie alleen 'n skare gelowiges wat in Christus hulle saligheid besit nie, maar ook 'n sigbare georganiseerde gemeenskap, ${ }^{77}$ waarvan Christus die Hoof is en waaroor Hy regeer. Die uitgangspunt vir die verwerkliking van die Koningskap van Christus word in die plaaslike kerk gevind, wat beskou word 


\section{In die Skriflig}

as die selfstandige, sigbare openbaring van die liggaam van Christus. Juis in die plaaslike kerk met sy ampte en bedieninge word die genade vanuit die pleroma bedien en moet die lidmate tot volheid in Christus groei. Dit is die punt waar die Koningskap en heerskappy van Christus sigbaar word en vanwaar dit oor die aarde moet versprei. Daarmee is ook reeds die kerkverband aangegee, want elke kerk tor plaatse is 'n openbaring van die ecclesia catholica, van die volk van God. ${ }^{78}$ Die weg is van die plaaslike kerk na die universele om die kerk as groeiende organisme onder die regering van Christus tot volheid te bring. Dit is die weg vanuit die pleroma van Christus na die volheid van die kerk onder die heerskappy van Christus. Om die katolisiteit in die universele kerk te rcaliseer is die vorming van kerkverband 'n roeping. Daartoe lei die presbiteriale stelsel ongehinderd.

\section{7) Die sigbaarmaking van die katolisiteit deur hedendaagse ekumeniese bewegings}

Die talle ekumeniese bewegings op kerklike erf in die huidige tyd moet getoets word om te bepaal of hulle die ware katolisiteit van die kerk sigbaar tot openbaring bring of nie. Die begrip „ekumenies” omvat die idee van 'n wêreldwye eenheid van die mensheid binne 'n bepaalde verband. ${ }^{79}$ Dus het dit betrekking op die sigbare sy van die kerk waardeur dit die universaliteit en eenheid op ' $n$ besondere wyse wil manifesteer. ${ }^{80}$ Ekumenisiteit kan nie as die volle sigbare of horisontale dimensie van die katolisiteit beskou word nie want katolisiteit omvat meer en lê die klem anders. Ekumenisiteit is 'n middel om tot katolisiteit te kom, tot die pleroma. Dit is dus ook 'n weg waarvolgens die katolisiteit sigbaar gemaak word. Tegelyk is dit ook die openbaring van 'n aspek van die gerealiseerde katolisiteit in die ecclesia militans, die eenheidsaspek daarin.

Ekumenisiteit moet in diens van die pleroma wees, want dit kan nooit doel in homself wees nie. Dit vind dan ook sy bestemming in die katolisiteit van die kerk. Dit het die sigbare realisering van die katolisiteit tot doel. Getoets hieraan kan teen die Wêreldraad van Kerke en talle ander ekumeniese bewegings argumente na vore gebring word om te bewys dat hulle nie die ware sigbaarmaking van die katolisiteit van die kerk is nie en ook nie kan wees nie.

Die uitweg uit die ekumeniese problematiek is om die katolieke eienskap van die kerk in die sentrum van die ekumeniese belangstelling en arbeid te plaas; om deur die ekumeniese strewe die katolisiteit sigbaar te maak. Dan word van die pleroma in Christus uitgegaan volgens die kwalitatiewe dimensie daarvan om dit beide vertikaal en horisontaal in die kerk te verwerklik.

\section{8) Die Gereformeerde Kerk in Suid-Afrika en die roeping tot sigbaarmaking van die katolisiteit van die kerk}

Krities moet ondersoek word in hoeverre die Gereformeerde Kerk in S.A. die katolisiteit sigbaar realiseer deur die struktuur van die kerk. Dan moet die oë eerstens na binne die eie volksverband gerig 
word waar die feitlike situasie die verdeeldheid van kerke met dieselfde belydenisskrifte is. Die Gereformeerde Kerk benader hierdie veelheid van kerke binne dieselfde volk vanuit die uitgangspunt: „Die veelheid van kerke word aanvaar maar nie om daarby te berus nie".81 Daar moet gesoek word na die ware katolieke eenheid in leer, diens en tug. Waar die ware eenheid gesoek word, moet tegelyk ook die ware katolisiteit, die pleroma van die Godsvolk, in die oog gehou en bevorder word. Die katolieke karakter van die kerk stel ook as eis dat die eenheid in een kerkverband tot uitdrukking gebring word. ${ }^{82}$ Die vraag moet dringend gevra word of deur die dialoog tussen die Afrikaanse kerke daar enigsins vordering was om die katolisiteit van die kerk sigbaar te vergestalt?

Om oor die volks- en nasionale grense heen die katolisiteit sigbaar te realiseer is kerkverband op ekumeniese vlak 'n vereiste. Die universele kerk moet as liggaam van Christus konkreet tot openbaring kom. Een wyse waarop dit geskied is interkerkelike korrespondensie waarby nie bly staan kan word nie omdat dit 'n swakker vorm van kerkverband is. ${ }^{83}$ Dit is 'n stap op die weg maar nog nie die einddoel nie. So is ook die Ekumeniese Sinode, wat nie in die ware sin van die woord ' $n$ sinode is nie, ${ }^{84}$ nog nie die volle verwesenliking van kerkverband nie. Tog lê in Artikel III van die konstitusi€ van die Gereformeerde Ekumeniese Sinode, wat die doel omskryf duidelik die katolisiteit in die gesigsveld en stel dit die dieper strewe om deur eenheid tot die volheid van die kerk te kom. Die Algemene Sinode, wat sy bestaan hoofsaaklik te danke het aan die sendingwerksaamhede van die Gereformeerde Kerk in S.A., is 'n grootse stap in die rigting van die sigbaarmaking van die katolisiteit. Die motivering vir die bestaan van die Algemene Sinode word gevind in 'n verskeidenheid in die liggaam van Christus, wat deur God self gegee en gewil is, en ook in die kerke onder die verskillende volke geopenbaar word.85 Die beginsel van verskeidenheid, wat in die Skrif gegrond is, is geen belemmering om die katolisiteit van die kerk sigbaar te maak nie, want die volheid van die kerk veronderstel juis die veelkleurige verskeidenheid; dus 'n volheid van en in die verskeidenheid. Die beginsel van eenheid in die verskeidenheid word gerealiseer deur kerkverband. So word die katolisiteit wêreldwyd sigbaar gemaak.

\section{9) Slot}

Om waarlik kerk van Jesus Christus te wees, moet die ecclesia militans die eienskappe van die ware kerk van Jesus Christus vertoon, d.w.s. die kerk moet wees soos Christus dit verorden, verkies en saamgeroep het.

Die kerk van Jesus Christus kan en mag niks anders as katolieke kerk wees nie. Die katolieke eienskap van die ecclesia militans moet, nieteenstaande alle gebrokenheid, verskeurdheid en onvoltooidheid wat die kerk na sy sigbare sy vertoon, tot sigbare realisering kom. Dit is die onvervreembare roeping van die kerk.

Die heerlike doel van die roeping tot sigbaarmaking van die katolisiteit van die kerk is ,sodat julle vervul kan word tot al 


\section{In die Skriflig}

die volheid van God"."so

Die eskatologiese perspektief waarmee die Heilige Skrif in die visioene van Johannes eindig, open 'n oorweldigende uitsig op die pleroma aan die einde van hierdie bedeling. Dan sal die groot sigbaarmaking plaasvind. Die tyd van aanskouing sal intree. Wanneer ,die getal van die uitverkorenes vol sal wees", ${ }^{87}$ sal „onse Here Jesus Christus uit die hemel” kom, ,liggaamlik en sigbaar, soos Hy opgevaar het, met grote heerlikheid en majesteit". ${ }^{88}$ Dan sal elke oog Hom sien, selfs hulle wat Hom deursteek het.si So eindig die Heilige Skrif met die visioene aangaande die Bruidskerk, die „vrou" van „die Lam" wat "haar gereed gemaak" het.90 Dit is die kerk van Christus wat sy pleroma kwantitatief en kwalitatief bereik het.

1 W. J. Snyman gebruik ook die woord sigbaarmaking. Die Kerk. (In Predikante van die Gereformeerde Gemeentes in S.A. Die kosbare goud. Kaapstad, Nasionale Pers, 1944, p. 214).

2 Bos, F. L. De kerk die wij geloven en belijden. Groningen, Niemeijer, 1950, p. 5. Veenhof, C. Om kerk te blijven. Amsterdam, Buijten \& Schipperheijn, 1966, p. 357. Vgl. ook 1 Kor, 2 : 14.

3 Snyman, W. J. Op. cit., p. 214.

$4 \mathrm{Vgl}$. die Rooms-Katolieke institusionalisme teenoor die uiterstes van spiritualisme wat nie die kerk deur 'n georganiseerde instituut sigbaar wil manifesteer nie. Tussen hierdie twee uiterstes word 'n groot variasie van opvattings gevind.

5 Snyman, W. J. Op. cit., p. 218.

6 In sy Epistula ad Smyrnaeos VIII, 2. Vgl. Berkhof, H. De katholiciteit der kerk. Nijkerk, C. F. Callenbach N.V., 1962, p. 10. Beinert, W. Um das dritte Kirchenattribut, 2 dle in 1. Essen, Ludgerus-Verlag Hubert Wingen, K. G. 1964, p. 36.

7 Kinder, E. Der evangelische Glaube und die Kirche. Berlyn, Lutherisches Verlagshaus, 1958, p. 25, voetnoot 2.

8 Vgl. Beinert, W. Op. cit., p. 407.

9 Ibid., p. 551-63. Seeberg, R. Lehrbuch der Dogmengeschichte, dle. Erlangen \& Leipzig, A. Deichert'sche Verlagsbuchhandlung, 1895, I, p. 291.

10 Beinert, W. Op. cit., p. 66.

11 Vgl. bv. die verklaring van Cyrillus. Aangehaal deur Berkhof, H. Op. cit., p. 13/14. Beinert, W. Op. cit., p. 70.

12 Deur teoloë soos Möhler (1796-1838) en J. H. Newman (1801-1890), wat die organiese denke in die teologie laat pasvat het. Die dominikaan A. de Poulpiquet stel in 'n artikel in 1909 dat die katolisiteit uit die geestelike kom. Hy fundeer die kwantitatiewe in die kwalitatiewe. Die Franse dominikaan Congar bou in dieselfde rigting voort en fundeer die ekklesiologie op die Christologie. Hy wil die begrip katolisiteit met die pleromagedagte vul.

13 Vgl. Jenkins, D. T. The nature of catholicity, London, Faber \& Faber, 1941. Die Evangeliese groep in die Anglikaanse Kerk het in 1950 hulle port oor katolisiteit die lig laat sien: The Fullness of Christ. The Church's growth into Catholicity. London, 1950. 
14 Bavinck, H. De Katholiciteit van Christendom en Kerk, Kampen, J. H. Kok N.V., 1968, p. 23. Na die Eerste Wêreldoorlog is heelwat oor Evangeliese katolisiteit geskryf. Söderblom voer dié term in. Vgl. o.a. Söderblom, N. Evangelische Katholizität. (In Festgabe für Adolf Deissmann zum 60. Geburtstag 7. November 1926. Tübingen, J. C. B. Mohr, 1927); Heiler, F. Evangelische Katholizität. München, Ernst Reinhardt, 1926; Bossevain, W. Th. Evangelische Katholiciteit. Leiden, E. J. Brill, 1929; Stãhlin, W. Katholizität, Protestantismus und Katholizismus. (In Katholizitât. Kerygma und Dogma, 6, 1960.

15 Schleiermacher, F. Der christliche Glaube nach den Grundfazen der evangelische Kirche. Berlyn, G. Reimer, 1842, p. 444.

16 Vgl. Barth, K. Die Kirchliche Dogmatik, IV, I. Zürich, A. C. Zollikon, 1945 , p. 783 e.v. Brunner, E. The christian doctrine of the church, faith and consummation. Dogmatics, III. London, Lutherworth Press, 1964, p. 122 e.v.

17 Calvyn, J. Institusie, IV, I, 2, 3, 9.

18 Locus de Ecclesia. (In College-dictaat een der studenten, p. 80/81).

19 Du Plessis, H. 'n Banier van die volke. Potchefstroom, Pro Rege-Pers Beperk, 1963, p. 14.

20 Vgl. Hand. $17: 26$.

21 Van der Walt, I. J. Eiesoortigheid en die sending. Potchefstroom, Pro Rege-Pers Beperk, 1963, p. 334 e.v.

22 De Psalmen, II. Kampen, J. H. Kok N.V., 1945, p. 47.

23 Op. cit., p. 141.

24 Ridderbos, H. Paulus. Ontwerp van zijn theologie. Kampen, J. H. Kok N.V., 1966, p. 386/387. Vgl. Ef. 1 : 10, Rom. 8 : 28; 9 : 11; Ef. 1 : 5, 9, 11; 3 : 11; 2 Tim. 1 : 9; Rom. 8 : 29; $11: 2 ; 1$ Kor. 2 : 7, Rom. 9 : 33; Ef. $2: 10 ; 3: 9$.

25 Vgl. Dijk, K. Van eeuwigheid verkoren. Delft, W. D. Meidema, 1952, p. 86. Berkouwer, G. C. De verkiezing Gods. Kampen, J. H. Kok, 1955, p. 154.

26 Van der Walt, I. J. Op. cit., p. 299.

27 Kraemer, $H$. The christian message in a non-christian world. London, The Edinburgh House Press, 1938, p. 417.

28 Dilschneider, O. A. Christus Pantokrator. Vom Kolosserbrief zür okumene. Berlyn, Käthe Vogt, 1962, p. 34.

29 Kinder, E. Der evangelische Glaube und die Kirche. Berlyn, Lutherisches Verlagshaus, 1958, p. 17 e.v.

30 Polman, A. D. R. Onze Nederlandsche Geloofsbelijdenis, III. Franeker, T. Wever, s.j., p. 274.

31 Ibid., p. 271.

32 Bavinck, $H$. De Katholiciteit van Christendom en kerk, p. 32.

33 Ibid., p. 30.

34 Berkhof, H. De Katholiciteit der kerk, p. 44. Vgl. Ef. $1: 22,23 ;$ Ef. 3 : 19b; $4: 10 ; 5: 18$; Kol. $1: 19 ; 2: 9,10$.

35 Vgl. Kol. $1: 19 ; 2: 9 ;$ Ef. $3: 19$.

36 Macgregor, G. Corpus Christi. London, Macmillan \& Co., 1959, p. 130.

37 Best, E. One Body in Christ. Cambridge, University Press, 1955, p. 144.

38 Ef. $5: 18$.

39 Ef. $4: 13$.

40 Berkhof, H. De Katholiciteit der kerk, p. 64/65.

41 Ibid., p. 65/66. 
42 Buys, P. W. Die Pleroma van Christus. Die Kerkblad, Jg. 72, no. 2021, $15 / 10 / 269$, p. $4 / 5$.

43 Kol. $2: 3 ; 3: 3 ; 2$ : 18.

44 Berkouwer, G. C. Dogmatische Studiën. De Kerk I. Eenheid en Katholiciteit. Kampen, J. H. Kok, 1970, p. 137.

45 Kol. 1 : 19.

46 Berkhof, H. De Katholiciteit der kerk, p. 86.

47 Bavin:k, H. Gereformeerde Dogmatiek, IV. Kampen, J. H. Kok, 1911, p. 329.

48 Veenhof, C. Volk van God. Amsterdam, Buijten \& Schipperheijn, 1969, p. 42. Noordmans, $O$. Gestalte en Geest. Amsterdam, Holland Uitgeversmaatschappij, 1956, p. 330/331. Ridderbos, H. Paulus. Ontwerp van zijn theologic, p. 522.

49 Vgl. Snyman, W. J. Die gebruik van die woord "Kerk" in die Nuwe Testament. Potchefstroom, Die Westelike Stem, 1949, p. 10.

50 Vgl. Nederlandse Geloofsbelydenis, art. 29.

51 Ridderbos, H. Paulus. Ontwerp van zijn theologie, p. 295 e.v.

52 Vgl. o.a. Ef. $1: 10 ; 1: 23 ; 4: 6 ; 4: 10 ; 4: 13 ;$ Kol. $1: 16 ; 1: 20 ; 3: 11$.

53 De Katholiciteit der kerk, p. 92/93.

51 Hfst. 2 : 8 .

55 Berkhof, H. De Katholiciteit der kerk, p. 92.

56 Luther, M. Vom weltlicher Oberkeit, wie weit man ihr Gehorsam schuldig sey. (In Berger, A. E. Luthers Werke, II. Leipzig \& Wien, Bibliographisches Institut ,1917, p. 75 .

57 Ibid., p. 90.

58 Bavinck, H. De Katholiciteit van Christendom en kerk, p. 23.

59 Heyns, J. A. Sterwende Christendom? Tafelberg-Uitgewers, 1969, p. 52.

60 Ibid., p. 14.

61 Ibid., p. 70/71.

62 De Katholiciteit der kerk, p. 107.

63 Berkouwer, G. C. De Dialektiese Theologie. (In Buffinga, N. e.a. Beproeft de Geesten. Culemborg, „De Pauw”, 1934, p. 86). Vgl. Barth, K. Der Römerbrief. München, Chr. Kaiser Verlag, 1923, p. 165 e.v., 417.

64 Op de Tweesprong. Franeker, T. Wever, 1964, p. 38/39.

65 Polman, A. D. R. Onze Nederlandsche Geloofsbelijdenis, I, p. 100.

66 Berkhof, H. De Katholiciteit der kerk, p. 105.

67 Heidelbergse Kategismus, vr. 8 \& 13. Vgl. ook Dordtse Leerreëls, hfst. 3 \& 4.

68 Nederlandse Geloofsbelydenis, art. 22.

69 Polman, A. D. R. Onze Nederlandsche Geloofsbelijdenis, III, p. 35.

70 Van der Walt, J. J. Christus as Hoof van die Kerk en die Presbiteriale Kerkregering. Doktorale proefskrif, P.U. vir C.H.O., Potchefstroom, 1974, p. $99 / 100$.

71 Ibid., p. 114a.

72 Bouwman, H. Gereformeerd Kerkrecht, I. Kampen, J. H. Kok, 1928, p. $262 / 263$.

73 Van der Walt, J. J. Op. cit., p. 10.

74 Van der Linde, G. P. L. Die grondbeginsels van die presbiteriale kerkregeringstelsel. Potchefstroom, Pro Rege-Pers Beperk, 1965, p. 78/19.

75 Van der Walt, J. J. Op. cit., 125/126.

76 Ibid., p. 11.

77 Vgl. Bouwman, H. Op. cit., I, p. 237. Van der Walt, J. J. Op. cit., p. $129 \& 139$. 
78 Bavinck, H. Gereformeerde Dogmatiek, IV, p. 407/408.

79 Duvenage, B. Die religieuse grondmotief van die konsepsies van Visser 't Hooft met betrekking tot die Wêreldraad van Kerke. Doktorale proefskrif, P.U. vir C.H.O., Junie 1969, p. 2.

80 Visser 't Hooft, W. A. Heel de kerk voor heel de wereld. Ambre \& Baarn, Bosch \& Keuning, 1968, p. 267.

81 Kommissierapport met betrekking tot interkerklike samespreking. (In Gereformeerde Kerk in S.A. Handelinge van die 33e Sinodale vergadering, 1958, p. 79).

82 Du Toit, J. D. Die Kerk VI. Ekumenisiteit. (In Versamelde Werke VII, Johannesburg, Dagbreek-Boekhandel, 1962, p. 509).

83 Vgl. Du Plessis, H. Kerkverband tot oor die nasionale grense. Koers, Jg. 33, Aug. 1965, no. 1, p. 39.

84 Ibid.

85 Ibid., p. 43.

86 Ef. $3: 19 \mathrm{~b}$.

87 Nederlandse Geloofsbelydenis, art. 37.

88 Ibid.

89 Openb. $1: 7$.

90 Openb. $19: 7$. 